\title{
Chronic wound mitomycin-c-induced animal models
}

\author{
Andreas Ariawan, Aditya Wicaksana, Aditya Rifqi Fauzi, Rosadi Seswandhana* \\ Division of Plastic and Reconstructive Surgery, Department of Surgery, Faculty of \\ Medicine, Public Health, and Nursing, Universitas Gadjah Mada/Dr. Sardjito General \\ Hospital, Yogyakarta, Indonesia
}

DOI: http://dx.doi.org/10.19106/JMedSci005002201803

\begin{abstract}
A chronic wound is a problem often encountered in medical care, especially in areas that do not have adequate health facilities. Several factors causing the injury are mechanical, chemical, electrical, or heat. Chronic inflammation and bacterial infections are two significant factors that affect the process of wound chronicity. Mitomycin-C (MMC) is widely used as intravenous, oral, or topical anti-cancer drug. Mitomycin-C that is topically administration to an injury can cause cross-linking and decrease or stop the DNA transcription process lead the injury will not reach the healing phase. Mitomycin-C works as an inhibitor of fibroblast proliferation that can inhibit wound healing process. This study aimed to investigate the effect of topical MMC administration in chronic wound animals model. Eight female Wistar rats aged 70 to 90 days and weighing between 300 to $350 \mathrm{~g}$ were used in this study. Wound model was made in the back area with a diameter of approximately $2 \mathrm{~cm}$. Rats were then divided into 2 groups. The first group as treatment group which the wound rats were compressed using sterile gauze moistened with 0.5 $\mathrm{mg} / \mathrm{mL}$ of MMC for five min and rinsed with $10 \mathrm{~mL}$ of saline solution. The second group as control which the wound rats were compressed by using sterile gauze moistened with saline for 5 minutes. On day 3,5, and 15, the wound profiles were observed consisting of wound diameter, necrosis, and consistency. The rat wound after MMC administration showed a slower decrease in diameter, fewer scar tissue formation, and development of necrotic tissue. In addition, the rat wound appeared as brownish-black, dry, thick chronic wounds and took longer to heal compared to those saline control. In conclusion, MMC administration inhibits the wound healing process on rat surgical wound model.
\end{abstract}

\section{ABSTRAK}

Luka kronis merupakan suatu masalah yang sering dihadapi terutama di daerah dengan fasilitas kesehatan yang tidak memadai. Faktor penyebab terjadinya luka adalah mekanik, kimia, listrik, atau panas. Inflamasi kronik dan infeksi bakteri merupakan dua faktor utama yang mempengaruhi proses kronisitas luka. Mitomisin-C (MMC) merupakan sediaan intravena, oral, dan topikal yang banyak digunakan pada keganasan. Pemberian MMC topikal pada luka dapat menyebabkan pertautan silang dan menurunkan atau menghentikan proses transkripsi DNA sehingga dapat menghambat penyembuhan luka. Mitomisin bertindak sebagai penghambat proliferasi fibroblast yang dapat menghambat penyembuhan luka. Penelitian ini bertujuan mengkaji efek pemberian MMC topical pada model hewan luka kronis. Delapan ekor tikus Wistar betina umur 70 hingga 90 hari, dengan berat antara 300 sampai $350 \mathrm{~g}$ digunakan dalam penelitian ini. Luka dibuat pada

\footnotetext{
* corresponding author: rosadi_seswandhana@ugm.ac.id
} 
daerah punggung yang bebas rambut dengan ukuran diameter sekitar $2 \mathrm{~cm}$. Tikus dibagi menjadi dua kelompok secara acak. Kelompok pertama sebagai kelompok perlakuan dikompres dengan kasa steril yang dibasahi MMC $0,5 \mathrm{mg} / \mathrm{mL}$ selama 5 menit kemudian dibilas dengan larutan salin $10 \mathrm{~mL}$. Kelompok kedua sebagai kelompok kontrol dikompres dengan kasa steril yang dibasahi dengan salin saja selama 5 menit. Pada hari ke-3, 5, dan 15 diamati profil luka tikus yang meliputi diameter luka, nekrosis, dan konsistensinya. Luka tikus setelah pemberian MMC menunjukkan penurunan diameter luka lebih lambat, pembentukan jaringan parut lebih sedikit dan terjadinya pembentukan jaringan nekrosis. Selain itu luka tampak berwarna lebih hitam kecoklatan, kering dan tebal dibandingkan kelompok kontrol. Dapat disimpulkan, pemberian MMC menghambat proses penyembuhan luka pada tikus.

Keywords: chronic wound - profile - mitomycin-c - wound healing - topical

\section{INTRODUCTION}

Chronic wounds are common medical problems, especially in areas where there are not adequate health facilities. Some factors that cause injury are mechanical, chemical, electrical, or heat. The wound healing process in the skin is a complicated cellular process, involving keratinocytes, fibroblasts, blood vessels, endothelial cells, and immune cells. Chronic injuries begin with acute onset injuries. Chronic wounds do not typically go beyond the initial stage of inflammation. An acute injury may become a chronic injury if there is no development in the wound healing process through hemostasis, inflammation, proliferation, and tissue maturation. The acute injury becomes chronic injury if it fails to improve within four weeks and does not show wound healing within eight weeks. Chronic inflammation and bacterial infection are two major causes that affect the chronicity of a wound. ${ }^{1-3}$ The ability to recognize chronic wounds by health care workers is essential, so that wound treatment is more appropriate, making wound healing faster and reducing wound care costs.

Mitomycin-C (MMC) is an anti-proliferative agent that inhibits DNA synthesis. It is widely used as an intravenous, oral, or topical anti-cancer drug. Mitomycin-C is given topically on the wound to form crosslinks and stop the DNA transcription process so that the wound will not undergo the healing process. Topical application of MMC to scar tissue will act as aninhibitor of proliferative fibroblast, thus inhibits wound healing. ${ }^{4-6}$

Mitomycin-C has a broad-spectrum effect in inhibiting the proliferation of many cell types, and when used topically, the biological effect is affected by the concentration and duration of exposure. Larger concentration and longer duration of exposure result in greater biological effects. Its clinical use in inhibiting scar tissue formation has been extensively studied. The rats are often used in animal model of wound healing studies, but there are limitations involving the anatomical differences in human skin and rats, the wound healing process and the immune system. Regarding the anatomy, rats have denser hair follicles and thinner dermis layers than the human skin. It is also showed that the rat skin heals through contractions, causing the edges of the wound to be closer to each other, forming bag zippers, and re-epithelization. In contrast, human skin heals the wound by re-epithelization only, where keratinocytes accumulate on the granulation tissue to cover 
the wound. With these differences, the study using rats are ideal for wound healing model. ${ }^{6-7}$ This preliminary study aimed to investigate the effect of topical MMC administration in chronic wound animals model.

\section{MATERIALS AND METHODS}

\section{Animal model}

Eight female Wistar rats aged 70 to 90 days, weighing between 300 and $350 \mathrm{~g}$ were used in this study. The animals were kept in separate cages in the Integrated Research and Testing Laboratory (LPPT), Universitas Gadjah Mada, Yogyakarta. Rats were given anesthesia using an intramuscular dose of ketamine $30 \mathrm{mg} / \mathrm{kg}$ of body weight. Following after anesthesia, the hairs on the back were shaved after they were cleaned by using $10 \%$ povidone-iodine. The wound was created in the back area that was free of hair with a diameter of approximately two centimeters in full thickness (FIGURE 1).

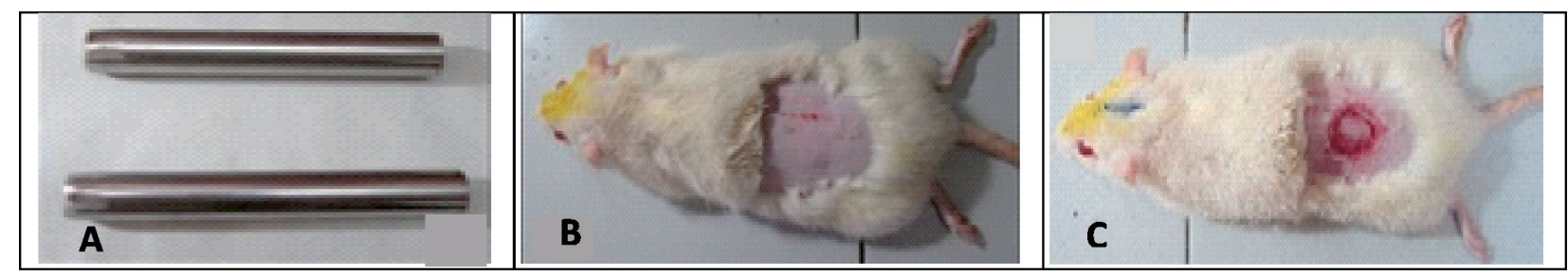

FIGURE 1. A: skin puncher; B: prepared and draped female rat; C: initial wound

\section{Animal treatment}

Eight rats were given a number from one to eight and randomly divided into two groups using the lottery method. In the first group as treatment group, the wound was compressed using sterile gauze moistened with $0.5 \mathrm{mg} / \mathrm{mL}$ of MMC for five minutes and rinsed with $10 \mathrm{~mL}$ of saline solution. The topical concentration value was adopted from the current literature. ${ }^{6}$ In the second group as control, the wound was compressed using sterile gauze moistened with saline solution without MMC for 5 minutes.

On the third day, the wound diameter was measured in both groups. We performed a necropsy on one of rats from each group; then we repeated the pretreatment for the rest of the rats in each group. On the $7^{\text {th }}$ and $15^{\text {th }}$ day, the wound skin diameters were measured in both groups. During the study, there were no sick or dead rats. The sample tissues were observed to notice any differences in the diameter of the wound, necrosis, scar formation and tissue color. This study was approved by the Ethical Committee of the Faculty of Medicine, Public Health, and Nursing, Universitas Gadjah Mada/Dr. Sardjito General Hospital under permit (KE/FK/594/EC/2015).

\section{Statistical analysis}

The wound skin diameters were analyzed by means of descriptive statistics following by visual and macroscopic analysis.

\section{RESULTS}

The results show that the wound skin diameters decreased more slowly in rats given with MMC, suggesting that the healing process took a longer time compared to the rats that given with saline solution (FIGURE 2 and TABLE 1). 


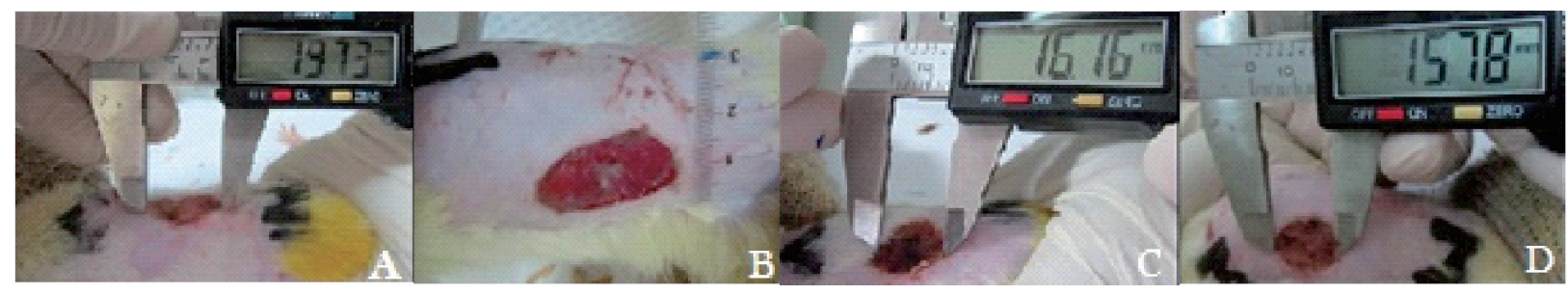

FIGURE 2. Groups of rats that received mitomycin-C (A: Day 0; B: day 3; C: day 7; D: day 15)

The formation of scar tissue in rats after MMC administration was smaller indicated by decreased scar tissue formation in chronic wounds. The rats after topical MMC administration showed a brownish color on the wound, and by day of 15 some of the lesions appeared to be black, dry, and hard, which were characteristics of the necrotic wounds.
The rats after saline solution administration did not reveal any necrotic tissue. The wound consistency in rats after topical MMC administration appeared brownish and after 15 days, coated by dark brown, dry, and hard brown tissue with surrounding tissue under local edema. The wound skin characteristics are shown in TABLE 1.

TABLE 1. The wound analysis based on wound diameter, scar formation, necrosis and wound consistency

\begin{tabular}{cccccc}
\hline Days & Rats & $\begin{array}{c}\text { Wound Diameter } \\
(\mathbf{m m})\end{array}$ & $\begin{array}{c}\text { Scar } \\
\text { formation }\end{array}$ & Necrosis & Wound consistency \\
\hline Day-0 & 1 & 19.73 & - & - & Red, moist \\
& 2 & 19.09 & - & - & Red, moist \\
Day-3 & 3 & 19.00 & - & + & Brownish, dry \\
& 4 & 19.00 & + & - & Pink, moist \\
Day-7 & 5 & 16.16 & - & - & Blackish brown, dry, thick \\
& 6 & 17.13 & ++ & +++ & Pink, soft \\
Day-15 & 7 & 15.78 & + & - & Slightly pale, soft \\
\hline
\end{tabular}

\section{DISCUSSION}

Our study showed that for the macroscopic parameters analyzed from the rats after topical MMCs administration was decreased in diameter of the wound, the fewer scar tissue formation and formed necrotic tissue, with hard consistency and blackish brown wounds. This results were in accordance with the previous studies which showed MMC administration topically in rats decreased wound strength and reduced scarring process indicating a chronic wound healing occurred. ${ }^{6,8}$ However, the mechanism of MMC in inhibiting fibroblast proliferation remains unclear.

Wound healing process consists of three phases that overlap each other, namely inflammation, proliferation and remodeling. ${ }^{9-11}$ After a skin injury, platelets are activated in the ruptured blood vessels and initiate clot formation to stop the bleeding. Platelets release a factor that stimulates the arrival of immune cells into the wound area of the blood circulation. Polymorphonuclear neutrophils 
(PMN) come first, followed by monocytes that rapidly differentiate into macrophages. Neutrophils produce many reactive oxygen species (ROS), proteases and proinflammatory cytokines to clean wounds. When the process is over, neutrophils will undergo apoptosis and be phagocytosed by macrophages. Macrophages will also phagocyte bacteria and debris to clean wounds. When the wound is clean, the proliferation process will begin, which is the process of tissue growth. Cells in the wound area will proliferate and migrate to replace lost tissue. Some of the cells involved are the extracellular matrix (ECM) or also called granulation tissue, which contains keratinocytes. During the remodeling phase, the final phase of the wound healing process, the granulation tissue becomes mature, and its mechanical strength increases. The complete process of wound healing occurs when myofibroblast and vascular cells start to apoptosis, leaving scar tissue rich in collagen. In chronic wounds, the proliferative and remodeling phases are not yet fully initiated nor established so that the wound remains in the inflammatory phase. The absence of tissue regeneration causes the wound to be healed incompletely. ${ }^{7}$ Observations in this study were conducted on days $0,3,7$, and 15 because the process of wound healing in rats is actually faster than humans. The rats only take about 10-14 days to heal their wounds. ${ }^{12}$ Based on our observations, the macroscopic wound healing becomes slower as we predicted earlier.

Some examples of chronic wounds are diabetic ulcers, venous ulcers, and pressure ulcers. Microscopically, chronic wounds have many inflammatory cells infiltrated, mainly neutrophils. It is thought that the cause of the chronic wound healing process is that fibroblasts lose their migration capacity and become unresponsive to growth factor signals. This change is indicated by the decrease of TGF- $\beta$ receptor levels and subsequent downward cascades in the wound healing process are disrupted. In previous studies, it was found that in chronic wounds, pro-inflammatory macrophages (M1) persist and did not transition into anti-inflammatory macrophages (M2), thus appeared to contribute to tissue repair disorders. The increased matrix of metalloproteinase (MMP) in chronic wounds is also thought to be the cause of decreased signaling and growth factor responsiveness. The process of reepithelization also becomes impeded by the decrease in the capacity of immune cells in chronic wounds, resulting in the buildup of debris cells. ${ }^{7,13}$

Formed scar tissues depend on the degree of fibrosis of the wound. The formation of fibrin during the hemostasis phase will be replaced by granulation tissue consisting of fibroblasts, macrophages and endothelial cells. Fibroblasts have an essential role in the wound healing process. Fibroblasts can synthesize collagen for an extracellular matrix useful as the foundation for epithelial cells and tissue epithelization. The study by Gray et al. ${ }^{14}$ reported that mitomycin-c has the ability to inhibit DNA synthesis to prevent the proliferation of fibroblasts in the long term. Experimental study on animals conducted by Lampus et al. ${ }^{15}$ reported that topical mitomycin-c was able to reduce total fibroblast in anoplasty wound healing trials in Wistar rats. Another study by Su et al. ${ }^{16}$ also shows the same result, finding topical MMC over $0.3 \mathrm{mg} / \mathrm{mL}$ can delay the wound healing via anti-cell proliferation effect and also that MMC inhibits angiogenesis of the wound via inhibition of vascular endothelial growth factor (VEGF).

The novelty of this study is that no macroscopic observation has been done with 
necrotic variables and wound consistency in chronic wound-induced animal models using MMC in any previous study. Typically, in the past, the assessed variables were degree of fibrosis, vascular proliferation and wound strength. ${ }^{6}$

Although this study is preliminary, it has shown that the application of topical MMC to surgical wounds in the rats resulted in disrupted healing process. Our long-term aims that motivate this study are to make an ideal chronic wound animal model that could be used to study diseases that are linked with chronic wound healing such as diabetic, venous, and pressure ulcers. We also intend to evaluate the possible adverse effects that might be caused by topical MMC on chronic wound healing models using different concentrations and more prolonged exposure over extended periods of time. Further studies are needed to examine these important salutogenesis issues. However, our small sample size could not provide sufficient power for our results and consequently larger samples are needed to provide clarification and confirmation of better results. We recommend that further research with microscopic tissue examination be performed with clinical trials involving human subjects.

\section{CONCLUSION}

In conclusion, the MMC inhibits wound healing process on rat surgical wound model as indicated by the formation of less scarring and longer wound healing duration that seen from slower diameter reduction. In addition, the wound tissue appears dry, hard, thick, and the surface appears colored blackish.

\section{ACKNOWLEDGEMENT}

We would like to thank to Integrated Research and Testing Laboratory (LPPT)
Universitas Gadjah Mada, Yogyakarta for their assistance along the study.

\section{REFERENCES}

1. Wall IB, Moseley R, Baird DM, Kipling D, Giles P, Laffafian I, et al. Fibroblast dysfunction is a key factor in the nonhealing of chronic venous leg ulcers. J Invest Dermatol 2008; 128(10):2526-40. http://dx.doi.org/10.1038/jid.2008.114

2. Zhao R, Liang H, Clarke E, Jackson C, Xue M. Inflammation in chronic wounds. Int $\mathrm{J}$ Mol Sci 2016; 17(12):2085. http://dx.doi. org/10.3390/ijms17122085

3. Eming SA, Martin P, Tomic-Canic M. Wound repair and regeneration: mechaisms, signaling and translation. Sci Transl Med 2014; 6(265):265sr6.

http://dx.doi.org/10.1126/scitranslmed. 3009337.

4. Paz MM, Zhang X, Lu J, Holmgren A. A new mechanism of action for the anticancer drug mitomycin C: menchanism-based inhibition of thioredoxin reductase. Chem Res Toxicol 2012; 25(7):1502-11. http://dx.doi. org/10.1021/tx3002065

5. Snodgrass RG, Collier AC, Coon AE, Pritsos C. Mitomycin C inhibits ribosomal RNA. J Biol Chem 2010; 285(25): 19068-75. http:// dx.doi.org/10.1074/jbc.M109.040477

6. Ribeiro FA, Guaraldo L, Borges JP, Vianna MR, Eckley CA. Study of wound healing in rats treated with topical and injected mitomycin-C. Ann Otol Rhinol Laryngol 2008; 17(10):786-90. http://dx.doi.org/10.1177/ 000348940811701 015

7. Krzyszczyk P, Schloss R, Palmer A, Berthiaume F. The role of macrophages in acute and chronic wound healing and interventions to promote pro-wound healing phenotypes. Front Physiol 2018;9:419. 
http://dx.doi.org/10.3389/fphys.2018.00419

8. Porter GT, Gadre SA, Calhoun KH. The effects of intradermal and topical mitomycin $\mathrm{C}$ on wound healing. OtolaryngolHead Neck Surg 2006;135(1):56-60.

http://dx.doi.org/10.1016/j.otohns.2006.02. 024

9. Gonzalez ACO, Costa TF, Andrade ZA, Medrado ARAP. Wound healing - a literature review. An Bras Dermatol 2016; 91(5): 61420.

http://dx.doi.org/10.1590/abd18064841.2016474

10. Shaw TJ and Martin P. Wound repair at a glance. J Cell Sci 2009; 122: 3209-13.

11. Gurtner GC, Werner S, Barrandon Y, Longaker MT. Wound repair and regeneration. Nature 2008; 453:314-21.

12. Gal P, Kilik R, Mokry M, Vidinsky B, Vasilenko T, Mozes S, et al. Simple method of open skin wound healing model in corticosteroid-treated and diabetic rats: standardization of semi-quantitative and quantitative histological assessments. Veterinarni Medicina 2008;53(12):652-9. http://dx.doi.org/10.17221/1973-VETMED
13. Martin P, Nunan R. Cellular and molecular mechanisms of repair in acute and chronic wound healing. British J Dermatol 2015; 173(2):370-8. http://dx.doi.org/10.1111/bjd.13954

14. Gray SD, Tritle N, Li W. The effect of mitomycin on extracellular matrix proteins in a rat wound model. Laryngoscope 2003;113(2):237-42.

http://dx.doi.org/10.1097/00005537200302000-00008

15. Lampus HF, Kusmayadi DD, Nawas BA. The influence of topical mitomycin-C on total fibroblasts, epithelialization, and collagenization in anoplasty wound healing in Wistar rats. J Pediatr Surg 2015;50(8):134751.

h t tp://dx.doi.org/10.1016/j. jpedsurg.2015.03.059

16. Su C, Sui $T$, Zhang $X$, Zhang $H$, Cao X. Effect of topical application of mitomycin-C on wound healing in a postlaminectomy rat model: an experimental study. Eur $\mathrm{J}$ Pharmacol 2012; 674(1):7-12.

h t t p://dx.doi.org/10.1016/j. ejphar.2011.10.028 